\title{
Akut Viral Hepatit A Seyri Esnasında Görülen Akut Tașsız Kolesistit
}

\author{
Acalculous Cholecystitis During the Course of Hepatitis A Virus Infection
}

\author{
Emine PARLAK, Mehmet PARLAK \\ Atatürk Üniversitesi Tıp Fakültesi, Enfeksiyon Hastalıkları Anabilim Dalı, Erzurum, Türkiye
}

\begin{abstract}
ÖZET
Hepatit A virüsü enfeksiyonu gelişmekte olan ülkelerde önemli bir sağllk sorunu oluşturmaktadır. Genellikle iyi huylu kendi kendini sınılayan bir hastalıktır, ancak atipik klinik bulgular ile ortaya çıkabilir Akut viral hepatitlerin (AVH) seyri esnasında safra kesesinde yapısal ve fonksiyonel değişiklikler görülebilir. Yirmi yaşında kadın hasta bulantı, kusma, yorgunluk, karın ağrısı, ateş ve sarılık şikayetleriyle kliniğimize kabul edildi. Fizik muayenesinde ikter, hepatosplenomegali ve sağ hipokondriyumda hassasiyet saptandı. Laboratuvar testlerinde bilirubin ve transaminaz düzeylerinde artış saptandı. Viral hepatit serolojisi Hepatit A infeksiyonunu gösteriyordu ve diğer nedenler negatifti. Ultrasonografi bulgularında taş olmaksızın genişlemiş safra kesesi gözlendi. Hastaya Hepatit A virüsünden kaynaklanan akut taşsız kolesistit tanısı kondu, konservatif tedaviye yanıt alındı. Sonuç olarak safra kesesinin etkilendiği akut viral hepatit olgularında gereksiz antibiyotik kullanımından ve cerrahi girişimden kaçınıImalıdır. (Viral Hepatit Dergisi 2013; 19(3): 156-8)

Anahtar Kelimeler: Akut viral hepatit, taşsı kolesistit, olgu sunumu
\end{abstract}

\section{ABSTRACT}

Hepatitis A virus infection constitutes an important health problem in developing countries. It is usually a benign self-limiting disease, but may present with atypical clinical findings. Acute viral hepatitis can be seen in the course of structural and functional changes in the gallbladder. A 20-year-old woman was admitted to our department with complaints of nausea, vomiting, fatigue abdominal pain, fever and jaundice. Physical examination revealed that the patient had icterus, hepatosplenomegaly and tenderness in right hypochondrium. Laboratory investigations revealed hyperbilirubinemia and elevated aminotransferases. Serology for viral hepatitis suggested acute hepatitis A infection and was negative for other causes. Ultrasonographically distended inflamed gallbladder without calculous was observed. Finally acute acalculous cholecystitis due to Hepatitis A virus was diagnosed and the patient responded to the conservative management. Affected by the gallbladder in patients with acute viral hepatitis, the unnecessary use of antibiotics and surgery should be avoided. (Viral Hepatitis Journal 2013; 19(2): 156-8)

Key words: Acute viral hepatitis, acalculous cholecystitis, case report

\section{Giriş}

Akut viral hepatitler tüm dünyada önemli bir sağlık sorunudur. Enfeksiyöz hepatitlerin çoğunluğunu hepatotropik etkenler olarak da bilinen hepatit $A, B, C, D, E$ virüsleri oluşturur $(1,2)$. Akut taşsız kolesistit, taş ve çamur olmaksızın safra kesesinin enflamasyonudur. Çocuklarda daha az görülmesine rağmen erişkinlerde akut kolesistitlerin \%5-10'unu oluşturur. Tanısı klinik, laboratuvar ve ultrasonografi bulgularına dayanır (1). Yüksek mortalite ile ilişkili olmasına rağmen bu gidiş erken teşhis ve tedavi ile engellenebilir (3). Bu yazıda akut viral hepatit A ( $\mathrm{AVH}-\mathrm{A})$ olarak takip edilen olguda komplikasyon olarak gelişen akut taşsız kolesistit olgusu sunulmuştur.

\section{Olgu}

Yirmi yaşında kadın hasta ateş yüksekliği, halsizlik, iştahsızlık, karın ağrısı, bulantı, kusma ve gözlerinde ve vücudunda sararma şikâyetleri ile başvurdu. Daha önceden tamamen sağlıklı olduğu halsizlik, iştahsızlık ve gözlerde sararma şikayetleri ile bir hafta devlet hastanesinde yattığı öğrenildi. Ateşi, karın ağıısı, kabızlığı olan kusmaları artan hasta kliniğimize yatırıldı. Başvurusunda ateş 37,9 ${ }^{\circ} \mathrm{C}$, kalp hızı 84/dk, kan basıncı 110/70 mmHg olarak bulundu. Fizik muayenesinde skleralar ve cilt ikterik, mukozalar kuru idi. Karaciğer kosta altından $3 \mathrm{~cm}$, dalak $2 \mathrm{~cm}$ olarak ele geliyordu. Batında sağ üst kadranda rebound alınıyordu.

Yazıșma Adresi/Address for Correspondence: Dr. Emine Parlak, Atatürk Üniversitesi Tıp Fakültesi, Enfeksiyon Hastalıkları Anabilim Dalı, Erzurum, Türkiye Tel.: +90 4422310686 E-posta: eparlak1@yahoo.com Geliş tarihi/Received: 26.07.2013 Kabul tarihi/Accepted: 27.09.2013

(c) Viral Hepatit Dergisi, Galenos Yayınevi tarafindan basılmıștır. / Viral Hepatitis Journal, published by Galenos Publishing. 


\section{Laboratuvar Değerleri}

Lökosit $8800 \mathrm{~mm}^{3}$, serum aspartat aminotransferaz (AST) $6447 \mathrm{U} / \mathrm{l}$ (1-35, alanin aminotransferaz (ALT) 4965U/l (1-30), gama glutamiltransferaz (GGT) 82U/l $(<38)$, alkalen fosfataz (ALP) 210U/l (30-120), direkt bilirubin (DB) 8,03 mg/dl (0-0,2), albümin $3,2 \mathrm{~g} / \mathrm{dl}$ (3,5-5,2), protrombin zamanı (PT) 21 sn (10-15,89), uluslararası normalleştirilmiş oranı (INR) 1,9 idi (Tablo 1). Hemogram ve amonyak değerleri normal idi. AntiHAV IgM (+), AntiHAV total (+), AntiHCV (-), HbsAg (-), AntiHBc IgM (-), AntiHBs (-), AntiHEV IgM (-) ve kapsid antigeni negatif bulundu. Salmonella, sitomegalovirüs ve Epstein-Barr virüs için serolojik testler negatif saptandı.

Batın ultrasonografi (USG) ve tomografisinde safra kesesi kontrakte, perikolesistik sıvı görüldü. Safra kesesi duvar kalınığı 4,6 mm olarak bulundu. Safra kesesinde taş veya çamur tespit edilmedi. Pankreas çevresinde bir kaç lenf bezi ve pelvik bölgede anekoik sıvı izlendi. Safra yolları normaldi. Sonografik Murphy işareti pozitif bulundu. Malignite, tıkanma, toksik ve alkolik hepatit ekarte edildi. Hasta AVH-A'ya bağlı kolesistit olarak yatııılı. Yatışının üçüncü gününde ateşi düştü. Klinik tamamen düzeldi, ultrasonografi bulguları on iki günde geriledi. Takiplerinde karaciğer fonksiyon testleri bir ayda normale döndü. Cerahi girişim ve antimikrobiyal tedaviye gerek kalmadan iyileşti.

\section{Tartışma}

Akut viral hepatit $A$, gelişmekte olan ülkelerde daha çok çocukluk çağında görülür (4). Bulaşmada fekal-oral yol önemli rol oynadığından Hepatit $A$, alt yapısı iyi olmayan bölgelerde daha fazla görülmektedir. Bu bölgelerde epidemilere neden olmaktadır. AVH-A enfeksiyonunun mevsim seçiciliği yaz sonu, sonbahar ve kış şeklindedir (5).

Yetişkinlerde daha gürültülü olan AVH-A enfeksiyonu çocuklarda hafif semptomlarla veya semptomsuz seyreder. Buna karşın vakaların \%15'inde hematolojik komplikasyonlar hemoliz, anemi, lökositoz, nötropeni, trombositopeni, immün trombositopenik purpura, trombositoz, asit, plevral efüzyon, fulminan hepatit, masif hepatik nekroz, uzamış kolestaz, akut taşsız kolesistit ve akut renal yetersizlik gibi komplikasyonlar bildirilmiştir (5-8).

Akut taşsız kolesistit, taş ve çamur olmaksızın safra kesesinin enflamasyonudur. Akut kolesistitlerin \%5-10'unu oluşturur. Ancak viral hepatitlerin seyri sırasında komplikasyon olarak akut taşsız kolesistit görülmesi nadir olarak yayınlanmıştır $(1,4,9,10)$. Sıklıkla sepsis, tifo, gastroenterit, pnömoni, giardiyazis ve otitis media gibi enfeksiyon ya da enfestasyonların seyri sırasında gelişir. llaveten travma, cerrahi girişim, şok, geniş yanık, sepsis, hamilelik, total parenteral nutrisyon ve/veya uzun süreli açlık durumu olan kritik hastalarda da görülebilmektedir $(3,4,11)$. Olgumuzda viral hepatit dışında risk faktörü tespit edilmedi.

Akut hepatitlerin seyrinde safra kesesinde yapısal ve fonksiyonel bazı değişiklikler gözlenmiştir. Kolesistitin patogenezi açık olmamakla birlikte safra stazı, immün mekanizmaların neden olduğu vaskülit, sepsis ve iskemi suçlanmıştır $(4,11)$. Mourani ve ark. (10), intrahepatik safra yolları ve safra kesesinde immünohistokimyasal yöntemlerle HAV antijenini gösterdikleri çalışmalarında virüsün kolestaz ve safra kesesi anormalliklerini, direkt safra epitelini enfekte ederek yaptığını bildirmişlerdir.

Akut taşsız kolesistit tanısı klinik, laboratuvar ve USG bulgularına dayanır. Teşhisinde klinik şüphe ve görüntüleme yöntemleri ile doğrulama esastır. Başlangıç tedavisi konservatiftir. Gangren veya perforasyon görülürse cerrahi müdahale uygulanır (8). Mortalitesi ve morbiditesi yüksektir (1). Sağ üst kadran ağrısı, ateş, sarılık, lökositoz ve karaciğer fonksiyon testi anormallikleri gibi spesifik olmayan bulguları olduğu için klinik tanı koymak zordur (3). Akut kolesistitin USG tanı kriterleri; sonografik Murphy işareti, safra kesesi duvar kalınlığının artışı (>4 mm), safra kesesinin genişlemesi, safra taşı, debris ekosu görünümünün olmaması, intra ve ekstra hepatik safra yollarında genişleme olmaması, safra kesesi etrafında sıvı birikimi, safra kesesi duvarında lineer ve strial hipoekojen görünümdür $(6,8,11)$. Hipoalbüminemi, asit yokluğunda safra kesesi etrafında sıvı birikimi, seroza altında ödem ve intramural gaz birikimi bildirilmektedir $(3,8)$. Sonografik Murphy işareti safra kesesi iltihabının iyi bir göstergesidir $(1,4,8)$.

Bizim vakamızda da kriterlere göre akut taşsız kolesistit tanısı konuldu. Bu durum geçicidir ve viremi düşük olduğunda yavaş yavaş gerilediği gösterilmiştir (9). Literatürde bizim vakamıza benzer şekilde cerrahi yapılmadan konservatif tedavilerle iyileşen örnekler bildirilmiştir $(4,8,9,11)$. Akut hepatitlerin seyri sırasında akut taşsız kolesistit görülen vakalarda trombositopeni varlığı safra kesesi gangren ve perforasyonu için uyarıcı olmalıdır (8).

Sonuç olarak AVH-A enfeksiyonu ülkemiz için hala önemli bir sağlık sorunudur. Asemptomatik seyirden fulminan hepatite kadar farklı klinik tablolar gösterebilir. Nadirde olsa hepatitlerin seyrinde de akut taşsız kolesistit görülebileceği unutulmamalıdır. Bu olguyu AVH-A seyrinde komplikasyon olarak akut taşsız kolesistit kliniği gelişebileceğini vurgulamak için sunduk. Bu olgularda gereksiz antibiyotik kullanımı ve invazif prosedürlerden kaçınılmalıdır.

Tablo 1. Laboratuvar Değerleri

\begin{tabular}{|l|c|c|c|c|c|c|}
\hline & Yatışta & $\mathbf{1 . ~ g u ̈ n ~}$ & 2. gün & 3. gün & 6. gün & 10. gün \\
\hline ALT (U/L) & 4965 & 5014 & 3235 & 3400 & 1119 & 394 \\
\hline AST (U/L) & 6447 & 6881 & 3230 & 1725 & 271 & 163 \\
\hline ALP (U/L) & 310 & 186 & - & - & - \\
\hline GGT (U/L) & 182 & 78 & 84 & - & - \\
\hline T. Bil. (mg/dL) & & 9,4 & 12,1 & 13,5 & 13 & 8,4 \\
\hline D. Bil. (mg/dL) & 8,03 & 8,6 & 8,2 & 12,4 & 12,06 & 7,2 \\
\hline Alb. (g/dL) & 3,2 & 3,2 & - & - & - \\
\hline PT (sn) & 21 & 27.5 & 26 & 20 & 12 & - \\
\hline INR & 1,9 & 2,5 & 2,4 & 1,8 & 1,15 & 0,9 \\
\hline
\end{tabular}




\section{Çıkar Çatışması: Bildirilmemiştir.}

\section{Kaynaklar}

1. Gora-Gebka M, Liberek A, Bako W, Szarszewski A, Kaminska B, Korzon M. Acute acalculous cholecystitis of viral etiology--a rare condition in children? J Pediatr Surg. 2008; 43: 25-7.

2. Dökmetaș I. HAV infeksiyonunun epidemiyolojisi ve patogenezi. Ed. Tabak F, Balık I, Tekeli E. Viral Hepatit 2007. 1. Baskı. İstanbul: Viral Hepatitle Savaşım Derneği. 2007; s: 52-60.

3. Huffman J L, Schenker S. Acute acalculous cholecystitis: A Review. Clin Gastroenterol H. 2010; 8(1): 15-22.

4. Özaras R, Mert A, Yilmaz M H, Celik A D, Tabak F, Bilir M et al. Acute viral cholecystitis due to hepatitis A virus infection. J Clin Gastroenterol. 2003; 37(1): 79-81.

5. Uluğ M, Yaman $Y$, Yapıcı F, Uluğ N C. Çocuk yaş grubu akut viral hepatit A olguları ve komplikasyonlarının irdelenmesi. Cocuk Enf Derg. 2010; 4: 65-70.
6. Hirota M, Takada T, Kawarada Y, et al. Diagnostic criteria and severity assessment of acute cholecystitis: Tokyo Guidelines. J Hepatobiliary Pancreat Surg. 2007; 14: 78-82.

7. Öncül M, Celiloğlu Can, Selimoğlu M A. Akut viral hepatit A ile plevral efüzyon birlikteliği: Olgu sunumu. Inönü Üniversitesi Tıp Fakültesi Derg. 2007: 14(2): 119-21.

8. Souza L J, Braga L C, Rocha N S M, Tavares R R. Acute acalculous cholecystitis in a teenager with hepatitis $A$ virus infection - A case report. Braz J Infect DIs. 2009; 13(1): 74-6.

9. E Erdem, Urgancı N, Ceylan Y, Kara N, Ozcelik G, Gulec S G. Hepatitis A with pleural effusion, ascites and acalculous cholecystitis. Iran J Pediatr. 2010; 20(4): 479-82.

10. Mourani S, Dobbs SM, Genta RM, Tandon AK, Yoffe B. Hepatitis A Virus-associated cholecystitis. Ann Intern Med. 1994; 120 398-400.

11. Kayabas Ü, Bayindir Y, Okuyan K. Akut Viral Hepatit A'ya Bağlı Nadir Bir Komplikasyon: Akut Kolesistit. Viral Hepatit Derg. 2007: 12(3): 133-6. 